\title{
PENDUGAAN KELIMPAHAN DAN SEBARAN IKAN DEMERSAL DENGAN MENGGUNAKAN METODE AKUSTIK DI PERAIRAN BELITUNG
}

\author{
Zulkarnaen Fahmi \\ Peneliti pada Pusat Riset Perikanan Tangkap, Ancol-Jakarta \\ Teregristrasi I tanggal: 10 Juli 2007; Diterima setelah perbaikan tanggal: 25 September 2007; \\ Disetujui terbit tanggal: 6 Mei 2008
}

\begin{abstract}
ABSTRAK
Sebagai bagian dari pendugaan stok ikan, metode akustik telah diterapkan untuk menduga kelimpahan dan sebaran ikan demersal di perairan Belitung. Pengamatan dilakukan pada bulan Juli dan September 2006 dengan alat penerima gema ikan EY 60, $120 \mathrm{kHz}$ bim terbagi. Hasil penelitian menunjukkan bahwa pada bulan Juli di perairan Barat Belitung, memberikan dugaan rata-rata sebaran kepadatan ikan kurang lebih 1.600 ind. per ha. Demikian pula, pada periode bulan September dengan dugaan rata-rata kepadatan kurang lebih 2.000 ind. per ha.
\end{abstract}

KATAKUNCI: metode akustik, ikan demersal, kelimpahan, perairan Belitung

\section{PENDAHULUAN}

Sumber daya perikanan di perairan Bangka Belitung merupakan salah satu potensi sumber daya alam yang banyak memberikan kontribusi bagi pembangunan di wilayah tersebut. Permintaan pasar akan sumber daya perikanan karang dan demersal di daerah tersebut terus meningkat sehingga menyebabkan tingginya ekploitasi sumber daya ikan yang berakibat pada penurunan produksi hasil tangkapan dari tahun ke tahun. Produksi hasil tangkapan ikan demersal pada tahun 2004 (54,6\%) dari total produksi $13.529 .087 \mathrm{~kg}$ dan menurun pada tahun 2005 menjadi $49,9 \%$ dari total produksi $11.110 .880 \mathrm{~kg}$ (Anonimus, 2005).

Stok sumber daya ikan di perairan Bangka Belitung merupakan sebagian kecil dari stok sumber daya ikan di wilayah pengelolaan perikanan Laut Cina Selatan dan Laut Jawa. Saat ini, data perikanan yang terkumpul pada umumnya merupakan hasil tangkapan nelayan yang didaratkan di pelabuhan perikanan atau di tempat-tempat pelelangan ikan. Ikan-ikan yang didaratkan tersebut pada umumnya berasal dari daerah penangkapan yang cukup jauh dari pulau.

Salah satu upaya dalam penyediaan data dan informasi pemanfaatan sumber daya ikan adalah menggunakan metode akustik. Pendugaan kelimpahan dan sebaran ikan demersal merupakan sasaran yang akan dicapai. Diharapkan data dari informasi tersebut dapat dimanfaatkan oleh Pemerintah Daerah setempat sebagai salah satu cara dalam mendeskripsikan potensi sumber daya ikan di kawasan perairan Belitung.

Tujuan dari penelitian ini adalah untuk mengamati aplikasi teknologi hidroakustik dalam menentukan kelimpahan ikan dengan mengukur intensitas echo yang dipantulkan oleh biota yang berada pada kolom air (Burcyzynski, 1982). Aplikasi teknologi hidroakustik pada penelitian ini dapat dengan cepat memperoleh data mengenai kepadatan ikan, kedalaman, dan topografi dasar perairan (Wijopriono et al., 2006).

\section{BAHAN DAN METODE}

Penelitian dilaksanakan selama tahun $2006 \mathrm{di}$ perairan sekitar Pulau Belitung melalui 2 kali pengambilan contoh, yaitu pada bulan Juli dan September. Pengambilan contoh dilakukan di 42 titik pengambilan contoh di perairan sekeliling Pulau Belitung.

Akuisisi data dengan cara menggunakan kapal nelayan di perairan sebelah barat Pulau Belitung dilakukan pada bulan Juli 2006 dengan batas geografis $2^{\circ} 33.328 \mathrm{~S}$ dan $107^{\circ} 39.230 \mathrm{E}-2^{\circ} 33.072 \mathrm{~S}$ dan $107^{\circ} 35.885 \mathrm{E}$, yaitu di sebelah utara Tanjung Binga serta $3^{\circ} 03.517 \mathrm{~S}$ dan $107^{\circ} 30.309 \mathrm{E}-3^{\circ} 01.636 \mathrm{~S}$ dan $107^{\circ} 26.996 \mathrm{E}$ di sebelah barat Pangkal Dudat. Akuisisi data di bagian timur Pulau Belitung dilakukan pada bulan September 2006 dengan batas geografis antara $2^{\circ} 37.353 \mathrm{~S}$ dan $108^{\circ} 12.418 \mathrm{E}$ di sebelah barat Tanjung Sengaran sampai $3^{\circ} 37.353 \mathrm{~S}$ dan $108^{\circ} 16.010 \mathrm{E}$ di sebelah barat Pulau Ayam Besar (Gambar 1).

Penelitian dilakukan dengan menggunakan Scientific Echosounder SIMRAD EY60 dengan sistem transducer split beam. Transducer terpasang dengan sistem temporary hull mounted system di kapal dengan frekuensi $120 \mathrm{KHz}$ (transducer ES-120). Perekaman data sepanjang alur pelayaran dilakukan dengan menggunakan piranti lunak ER60 yang menghasilkan data dengan format RAW yang akan dianalisis lebih lanjut dengan piranti lunak Sonar 4. 
Penentuan panjang dan jarak antar kaki (leg) serta arah pelayaran berdasarkan pada luas daerah yang dicakup serta waktu yang tersedia seperti dikatakan oleh Johannesson \& Mitson (1983). Alur pelayaran pengambilan data dilakukan dengan menggunakan bentuk transek sistematic zig-zag transect (MacLennan, 1990) yang dimodifikasi sesuai dengan kondisi perairan. Trek dimulai dari sebelah utara menuju ke bagian selatan. Wilayah perairan yang disurvei adalah perairan karang yang dangkal, mulai dari kedalaman $5 \mathrm{~m}$ sampai kedalaman maksimum $40 \mathrm{~m}$, dan berjarak sekitar $4 \mathrm{nmi}$ dari pantai. Hal ini bertujuan untuk menduga kepadatan ikan karang yang berada di perairan Pulau Belitung.

Pengintegrasian hasil deteksi dilakukan oleh EY60 dengan menggunakan metode echo integrasi menurut MacLennan (1990). Pengaturan sinyal pancar EY60 pada saat survei dapat dilihat pada Tabel 1.
Pengaturan ini didasarkan pada besar echo sasaran tunggal (single target) yang berasal dari ikan yang pada umumnya berkisar -60 sampai $-20 \mathrm{~dB}$ (MacLennan \& Simmonds, 1992). Perekaman data dilakukan pada kolom perairan sekitar $3 \mathrm{~m}$ dari dasar perairan dengan sasaran ikan demersal yang habitatnya berada di dasar perairan. Data akustik yang dihasilkan dari file-file dalam bentuk echogram terdiri atas 3 jenis file, yaitu RAW, Idx, dan Bot yang merupakan satu kesatuan file.

\section{Pengolahan dan Analisis Data}

Kegiatan pengambilan contoh akustik di bagian barat Belitung meliputi transek yang menghasilkan 22 leg, di mana jarak tiap leg bervariasi menurut kondisi daerah yang survei, sedangkan di bagian timur menghasilkan 20 leg. Pada pengolahan file dari tiaptiap leg tersebut dibagi lagi dalam skala yang lebih

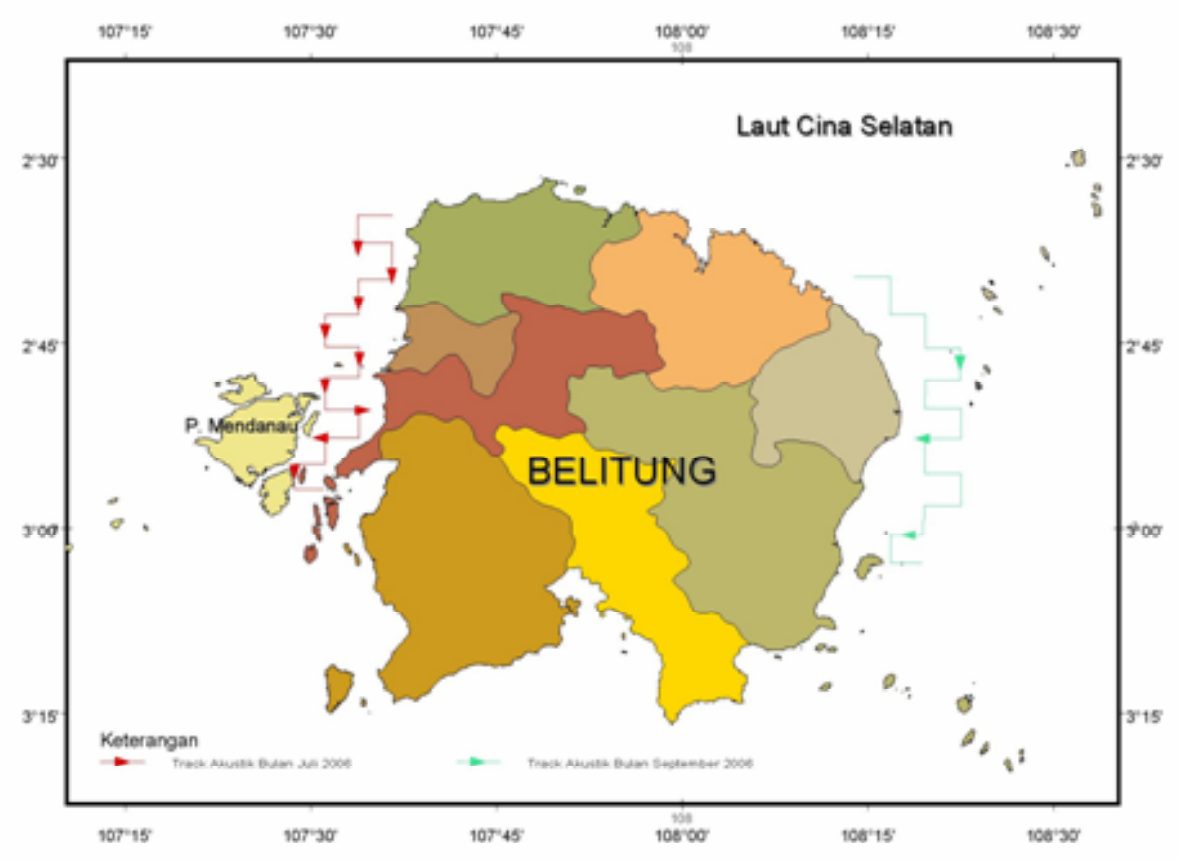

Gambar 1. Jalur transek akustik di Pulau Belitung pada bulan Juli dan September.

Tabel 1. Pengaturan parameter untuk pengoperasian EY60

\begin{tabular}{lc}
\multicolumn{1}{c}{ Parameter } & Nilai \\
\hline Frequency & $120 \mathrm{KHz}$ \\
Pulse Duration & $0,128 \mathrm{~ms}$ \\
Power transmit & $50 \mathrm{watt}$ \\
Sound speed & $1.545 \mathrm{~m} / \mathrm{s}$ \\
Absorption Coefficient & $41,59 \mathrm{~dB} / \mathrm{km}$ \\
SV threshold & $-70 \mathrm{~dB}$ \\
TS threshold & $-60 \mathrm{~dB}$ \\
\hline
\end{tabular}


sempit atau yang sering elementary sampling distance unit. Hal ini bertujuan agar data yang diolah menghasilkan suatu yang lebih detail terutama untuk menggambarkan sebaran spasial ikan demersal tersebut.

Dalam pengolahan ini elementary sampling distance unit yang dipakai adalah $1 \mathrm{~nm}$. Hasil pengolahan diperoleh 150 elementary sampling distance unit per $1 \mathrm{~nm}$ sehingga dapat diperkirakan panjang trek yang ditempuh waktu akuisisi data adalah $150 \mathrm{~nm}$ atau kurang lebih $270 \mathrm{~km}$.

Analisis data akustik yang meliputi interpretasi visual dan ekstraksi data dilakukan dengan menggunakan piranti lunak yang telah diberikan, yaitu Sonar 4. Pengolahan data akustik dalam bentuk echogram hasil akuisisi ER60 melalui tahapan compress atau diconvert terlebih dahulu sebelum diolah menggunakan piranti lunak Sonar 4. Jejak sasaran ikan yang terdeteksi selama akuisisi data akustik dikatakan dalam nilai integrator sA dalam unit $\mathrm{m}^{2} \mathrm{nmi}^{-2}$ dan sebaran nilai target strength yang menunjukkan variasi dari ukuran ikan dalam unit $\mathrm{dB}$.

Strata kedalaman yang dianalisis untuk ikan demersal adalah $3 \mathrm{~m}$ dari dasar perairan. Data yang dihasilkan berupa data dari echo sasaran tunggal (single echo detection), meliputi jumlah sasaran yang terdistribusi dalam nilai target strength, sA single echo detection, area density single echo detection, dan volume density single echo detection. Sedangkan data yang dihasilkan dari sistem integrasi gema atau amplitudo echogram lebih mengarah pada nilai-nilai total dari kolom perairan tersebut. Semua data-data tersebut yang nanti akan menghasilkan suatu nilai kepadatan atau densitas dan biomassa. Selain itu, data penunjang lain dapat diperoleh juga seperti posisi geografis, Sv (dB), jumlah ping, dan jarak pelayaran. Data ini dipakai dalam penentuan elementary sampling distance unit. Data hasil olahan Sonar 4 dapat disimpan dalam bentuk file ataupun dapat langsung diekstrak dalam format excel. Selanjutnya, bentuk data tersebut ditabulasi dalam format excel untuk perhitungan jumlah, ukuran, dan densitas ikan demersal, ditampilkan dalam bentuk grafik dan sebaran horisontal sehingga dapat dilihat hubungan antara nilai-nilai tersebut berdasarkan pada posisi geografis.

Distribusi spasial jumlah dan ukuran ikan demersal secara geografis diperoleh dari data distribusi target strength berdasarkan pada data akustik trek, sedangkan data lahan densitas untuk mengatakan kepadatan ikan-ikan tersebut dalam suatu kolom perairan dalam hal ini dikatakan dalam ekor per satuan hektar ( $f$ per ha).

\section{HASIL DAN BAHASAN \\ DISTRIBUSI HORISONTAL STOK IKAN DEMERSAL}

Pada pengolahan dan analisis data untuk ikan demersal menghasilkan suatu gambaran mengenai pola distribusi secara horisontal, baik untuk sebaran ukuran maupun kepadatan ikan. Mengingat habitat dari ikan demersal yang berada di dekat dasar perairan, maka analisis data terfokus pada satu strata kedalaman, yaitu $3 \mathrm{~m}$ dari dasar perairan, tidak seperti pengolahan data untuk ikan pelagis yang dapat dibagi ke dalam beberapa strata kedalaman sehingga dapat dilihat pola distribusi vertikal. Nilai target strength yang didapat dari backscattering cross section diambil pada kolom perairan $3 \mathrm{~m}$ dari dasar perairan kemudian dibagi ke dalam 12 kelas target strength.

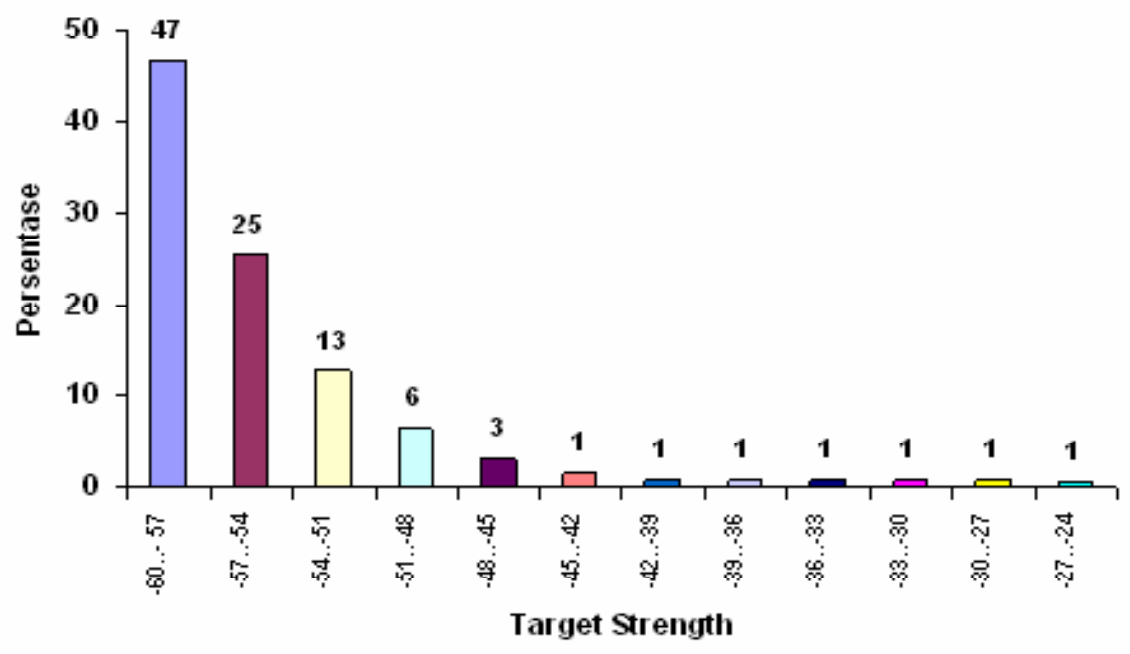

Gambar 2. Penyebaran target strength di perairan barat Belitung, bulan Juli 2006. 


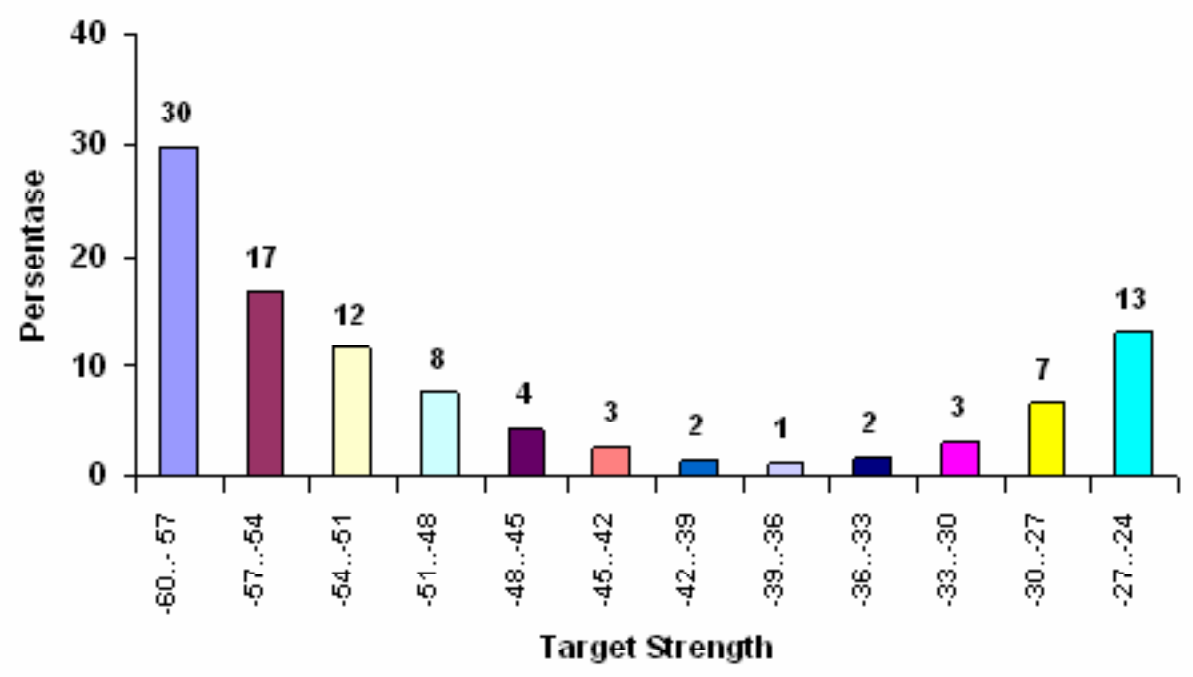

Gambar 3. Penyebaran target strength di perairan timur Belitung, bulan September 2006.

Distribusi target strength dan densitas lahan ikan secara mendatar dapat memberikan gambaran tentang jumlah, ukuran, dan kepadatan ikan berdasarkan pada posisi geografis. Persentase distribusi kelas target strength di bagian barat dan timur Belitung dapat dilihat pada Gambar 2 dan 3.

Dari gambaran tersebut dapat dilihat terdapat perbedaan antara ikan yang berada di sebelah barat Belitung dengan ikan di sebelah timur terutama dalam ukuran ikan yang terekam. Ikan demersal di sebelah barat pada bulan Juli 2006 mempunyai ukuran yang lebih kecil dibandingkan dengan ikan di sebelah timur (bulan September 2006).

Hal ini ditunjukkan oleh ikan-ikan di sebelah barat Belitung yang didominasi oleh ikan dengan ukuran 60 sampai $-57 \mathrm{~dB}$ atau setara dengan panjang ikan kurang dari $5 \mathrm{~cm}$ sebanyak 12.300 ekor (47\%). Kelompok ukuran ikan dengan panjang $5-10 \mathrm{~cm}$ atau setara dengan kelompok target strength - 57 sampai $51 \mathrm{~dB}$ adalah kurang lebih 10.000 ekor (38\%). Selain itu, kelompok ukuran panjang ikan 10 sampai $15 \mathrm{~cm}$ (-51 sampai $-48 \mathrm{~dB}$ ) ditemukan kurang lebih 1.600 ekor. Ukuran ikan dengan panjang $15-20 \mathrm{~cm}$ kurang lebih 800 ekor, dan kelompok panjang ikan $20-25 \mathrm{~cm}$ adalah 400 ekor. Sedangkan ukuran ikan besar lebih dari $30 \mathrm{~cm}$ (-36 sampai $-24 \mathrm{~dB}$ ) ditemukan kurang lebih 1.100 ekor 4\% (Gambar 2).

Kondisi di sebelah timur Belitung menunjukkan bahwa ukuran ikan kecil dan besar dijumpai relatif merata yakni pada ukuran panjang ikan kurang dari 5 $\mathrm{cm}$ dan panjang $5-10 \mathrm{~cm}$ masing-masing $13 \%$ atau sekitar 3.000-3.500 ekor pada setiap kelompok target strength. Begitu pula dengan ukuran ikan besar (-36 sampai -24 dB) dijumpai jumlah hampir sama dengan ukuran ikan kecil (12\% atau kurang lebih 3.200 ekor). Sedangkan kelompok ikan dengan panjang $10-15 \mathrm{~cm}$ (3\%), kelompok panjang ikan $15-20 \mathrm{~cm}$ (kurang lebih $2 \%$ ) dan jumlah ikan pada interval panjang $20-30 \mathrm{~cm}$ (1\%) masing-masing terdeteksi jumlah ikan pada setiap kelompok target strength kurang dari 1.000 ekor (Gambar 3).

Hasil deteksi akustik di bagian barat Belitung memperlihatkan adanya perbedaan sebaran nilai target strength yang terdapat di sebelah utara dan selatan. Ikan-ikan demersal di sebelah utara (leg 1 sampai 9) mempunyai ukuran yang lebih kecil dibandingkan dengan di sebelah selatan, digambarkan oleh target strength antara - 60 sampai $-57 \mathrm{~dB}$ dan antara -57 sampai $-54 \mathrm{~dB}$. Sedangkan di sebelah selatan pulau (leg 10 sampai 22) dijumpai banyak ikan dengan target strength - 57 sampai -48 dB (Gambar 4).

Demikian pula, di perairan timur Belitung terdapat sebaran nilai target strength pada leg 1-9 tetapi terlihat ikan-ikan ukuran besar hampir mendominansi pada leg 10-20 dari arah utara ke arah selatan dengan target strength -27 sampai -24 dB (Gambar 5).

Hasil analisis data akustik di perairan barat Belitung didapatkan bahwa ukuran ikan di bagian utara walaupun berukuran lebih kecil tetapi mempunyai jumlah yang lebih besar setiap nautical mildibandingkan ikan yang berada di sebelah selatan. Rata-rata ikan di sebelah utara mempunyai kepadatan kurang lebih 2.800 ekor per ha. Di bagian selatan, 


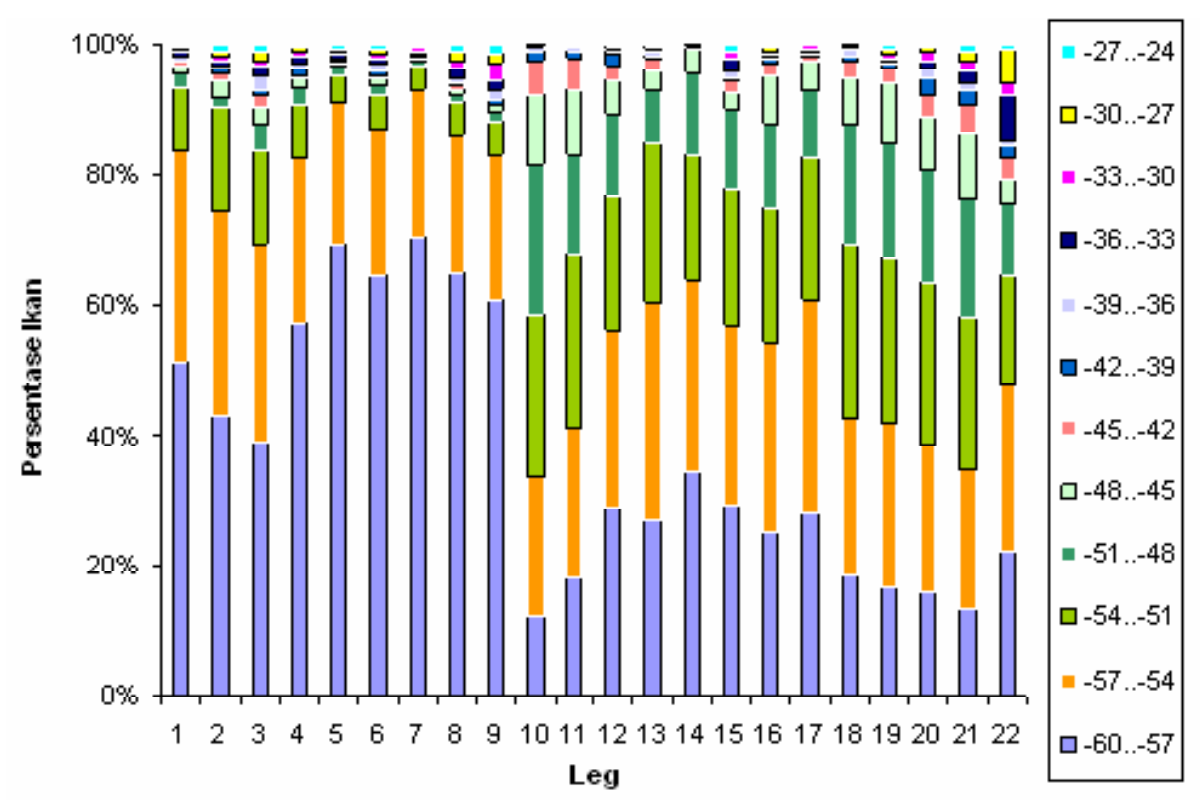

Gambar 4. Persentase target strength yang terdeteksi tiap leg berdasarkan pada nilai target strength di perairan barat Belitung.

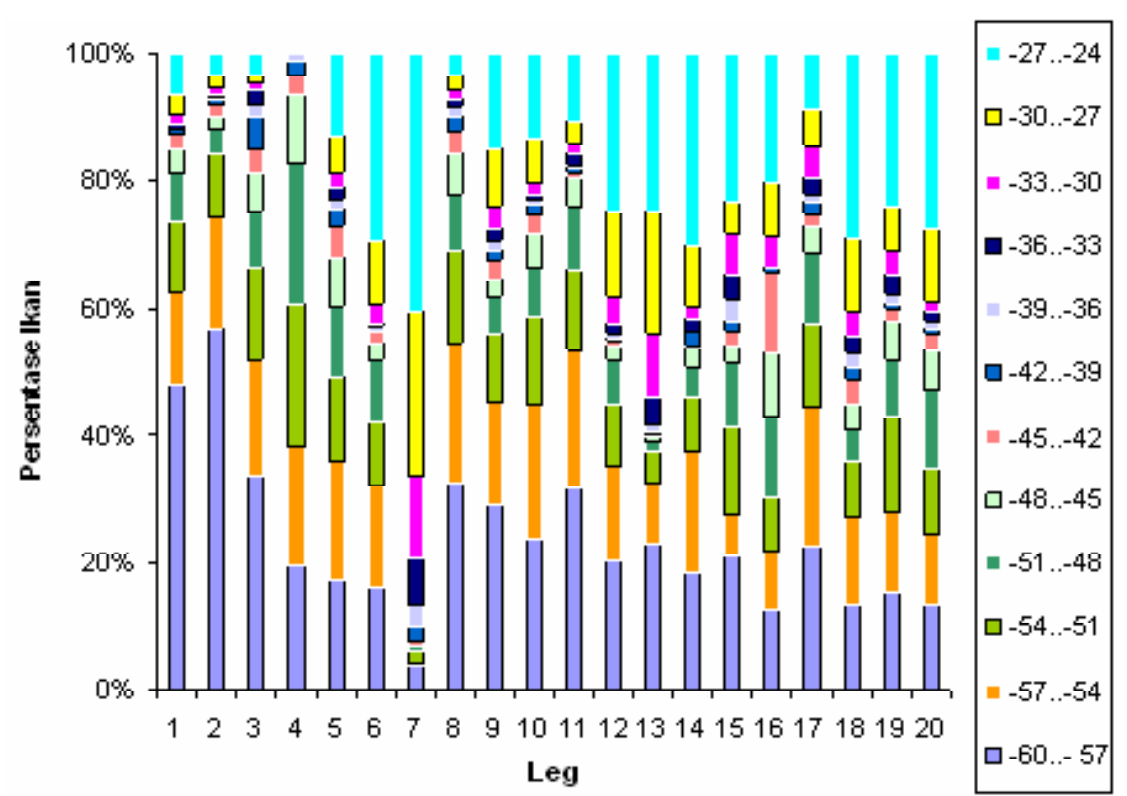

Gambar 5. Persentase target strength yang terdeteksi tiap leg berdasarkan pada nilai target strength di perairan timur Belitung.

ukuran ikan demersal lebih besar dan bervariatif, tetapi jumlah lebih sedikit, yakni rata-rata 400 ekor per ha.

Pengambilan contoh akustik di timur Belitung dengan menggunakan kapal nelayan pada bulan September 2006 menunjukkan rata-rata ukuran ikan relatif besar di perairan utara daripada di selatan Belitung. Nilai target strength -42 sampai $-39 \mathrm{~dB}$ menyebar rata di perairan tersebut, sementara nilai target strength -31 sampai $-28 \mathrm{~dB}$ menyebar rata di bagian selatan.
Kepadatan stok ikan yang terdeteksi di bagian timur Belitung menunjukkan rata-rata kepadatan di bagian utara lebih tinggi daripada di sebelah selatan, ditunjukkan oleh nilai rata-rata kepadatan 3.000 ekor per ha. Sementara itu, di bagian selatan nilai kepadatan rata-rata kurang dari 800 ekor per ha.

Hasil tersebut menunjukkan bahwa kepadatan ikan pada periode survei lebih banyak terdeteksi di perairan pantai yang relatif dangkal. Hal ini tampak dari deteksi akustik yang memberikan gambaran tentang sebaran densitas lahan (ekor per ha) ikan 
demersal pada strata $3 \mathrm{~m}$ dari dasar perairan. Pola sebaran densitas ikan demersal di daerah dekat pantai dan daerah gugusan pulau mempunyai kepadatan lebih tinggi tetapi rata-rata ukuran lebih kecil. Dengan perkataan lain, banyak terdeteksi ikan demersal berukuran kecil yang membentuk gerombolan (schooling) di dekat dasar perairan, ditunjukkan dengan nilai-nilai densitas yang cukup besar.

\section{KESIMPULAN}

1. Hasil survei akustik menunjukkan bahwa ikan karang di sebelah barat Pulau Belitung mempunyai ukuran yang lebih kecil bila dibandingkan dengan ikan di sebelah timur Pulau Belitung.

2. Di sebelah timur Pulau Belitung ikan besar mendominasi hampir di seluruh lokasi pengambilan contoh. Sementara itu, di sebelah barat pulau, ukuran ikan cenderung lebih kecil bila dibandingkan dengan ukuran ikan yang ada di Selatan Tanjung Pandan.

3. Kepadatan ikan di perairan utara Belitung lebih tinggi bila dibandingkan dengan di bagian selatan pulau. Di bagian utara Tanjung Pandan kepadatan ikan mencapai 2.800 ekor per ha, sedangkan di selatan Tanjung Pandan hanya 400 ekor per ha. Di bagian utara Manggar kepadatan ikan lebih tinggi yaitu 3.000 ekor per ha, sedangkan di selatan Manggar 800 ekor per ha.

\section{PERSANTUNAN}

Kegiatan dari hasil riset pemetaan pemanfaatan sumber daya perikanan di perairan Bangka Belitung, T .A. 2006, di Pusat Riset Perikanan Tangkap-Ancol, Jakarta.

\section{DAFTAR PUSTAKA}

Anonimus. 2005. Statistik Perikanan Pelabuhan Perikanan Nusantara Tanjung Pandan. Perikanan Pelabuhan Perikanan Nusantara Tanjung Pandan.

Burczynsky, J. 1982. Introduction to the use of sonar system for estimating fish biomass. FAO Fisheries Technical Paper No.119. Rome. FAO.

Johanesson, K. A. \& Mitson, R. B. 1983. Fisheries acoustic: A practical manual for biomass estimation. FAO Fish. Tech. Pap.240. 249 pp.

MacLennan, D. N. 1990. Acoustical measurement of fish abundance. Journal of the Acoustical Society of America. 87 (1): 1-24.

MacLennan, D. N. \& E. J. Simmonds. 1992. Fisheries Acoustics, Fish, and Fisheries. Series 5. Chapman and Hall. London. 325 pp.

Wijopriono, M. Natsir, A. Slotte, \& A. Priatna. 2006. Spatial distribution and shoaling behaviour of fishery resources in the waters off western coast of Aceh: Preliminary results from the post tsunami expedition 2005. Indonesian Fisheries Research Journal. (12):15-25. 